\title{
Ecotoxicological investigations of milking cow slurry and changes of oestrogenic compounds in the solid and liquid phase
}

\author{
Eduárd Gubó ${ }^{1} \cdot$ Ildikó Kiss-Szarvák $^{2} \cdot$ Mishele Erdenebaatar $^{3} \cdot$ Richárd Gubó $^{4}$. \\ Bence Horváth $^{1} \cdot$ Pál Szakál $^{1} \cdot$ Judit Plutzer $^{2}$ \\ ${ }^{1}$ Faculty of Agricultural and Food Science, Széchenyi István University, 9200 Mosonmagyaróvár, Vár tér 2, Hungary \\ ${ }^{2}$ National Public Health Center, Budapest, Hungary \\ 3 Óbuda University, Budapest, Hungary \\ ${ }^{4}$ Department of Applied and Environmental Chemistry, University of Szeged, Szeged, Hungary
}

Received: 25 June 2021 /Revised: 16 October 2021/Accepted: 18 October 2021/Published online: 15 November 2021 (C) The Author(s) 2021

\begin{abstract}
Due to the appearance of intensive livestockrearing systems since the 1970 s, a vast amount of liquid manure (slurry) has been produced. The application and utilization are partly regulated for this special substance, which contains urine, excrement, process water, and other chemicals, such as insecticides and disinfectants. Our research was conducted on a slurry management system of a dairy cattle farm, focusing on the investigation of the presence of oestrogenic substances and toxicity of slurry before and after using a separator technology. Yeast oestrogen screen shows in this study that the separation of the liquid and solid phases of slurry contributes to the reduction in oestrogenic substances. Based on the toxicological studies, the growth inhibition of algae was $93 \%$, and the inhibition of the germination of higher plant seeds was $25 \%$, without separation. After separation of the phases, growth and germination were comparable with the negative control; moreover, some stimulation was detected. Consequently, harmful substances were removed with the suspended solid phase. From the present study, we can conclude that stakeholders should support separation technology in intensive livestock-rearing systems, and ecotoxicological investigations obviously help the risk management of slurry utilization. To our best knowledge, this is the first paper presenting detailed and complex toxicological study on slurry samples.
\end{abstract}

Keywords Slurry · Dairy farm · Oestrogen · Toxicology

Eduárd Gubó

gubo.eduard@gmail.com

\section{Introduction}

Amongst natural elements, soil plays a significant role in food production; therefore, contamination-free, goodquality soil is highly important (Kopittke et al. 2019). The rapid growth of the agriculture industry, widespread drug utilization, and intense animal husbandry technologies are causing problems that have not been considered before (Liu et al. 2018; Oliver and Gregory 2015; Pimentel and Burgess 2013). Watering with slurry is a good solution for farmers aiming to get rid of the by-product and useful for agricultural landowners who use it as nutrient for plants. Slurry can only be released into an agricultural area in possession of a soil protection authority permit (CXXIX Act 2007) in Hungary. The authorization is issued by the Office of Agriculture Directorate and is based on soil and slurry testing. Decree 90/2008 (VII.18) of the Ministry of Agriculture and Rural Development provides that designated areas need a soil protection plan that should include detailed load calculations for the applied nutrient content. Nitrate-sensitive areas are subject to even stricter regulations, based on different decrees (Decree 27/2006 (II.7), Decree 59/2008 (IV.29)). The Nitrates Directive (Council Directive 91/676/EEC) promotes the use of good farming practices by preventing nitrates from agricultural sources and protects water quality across Europe (Goodchild 1998).

During the authorization process, the slurry is tested for its nutrient content, dissolved salts and other elements (e.g. $\mathrm{N}$ forms, $\mathrm{P}, \mathrm{K}, \mathrm{Ca}, \mathrm{Mg}, \mathrm{Na}, \mathrm{Fe}, \mathrm{Mn}, \mathrm{Cu}, \mathrm{Zn}$ ), but this testing does not include ecotoxicological studies. Although the nutrient content of the slurry is high, it could contain other harmful elements (e.g. disinfectants, drug residues, hormones) that can have negative effects on plants, soil or other organisms (Adeel et al. 2017; Goeppert et al. 2015). 
According to the literature, steroid oestrogens such as estrone (E1), oestradiol (E2), estriol (E3), and synthetic oestrogen (EE2) can be found everywhere in the soil as a result of watering with slurry and manure applied to agricultural fields originating from intense animal husbandry operations (Goeppert et al. 2014; Zheng et al. 2008; Adeel et al. 2017). The emissions of livestock kept in the USA and the European Union together exceed $83000 \mathrm{~kg}$ of natural oestrogens (E1, E2 and E3) annually, which is double the total of human emissions (Adeel et al. 2017). Oestrogens (E2, E1, and E3) are predominantly female hormones responsible for the healthy maintenance of reproductive tissues, like breast, skin, and brain. In men, the testicles produce small amounts of oestrogen (Lai et al. 2000). The oestrogenic potential of different chemicals is most often expressed as the relative potential to the $17 \beta$-E2 reference compound. The quality of the compounds plays a determinative role, as each oestrogenic compound can have a different effect on the receptors. From Coldham et al., it is well known, that compared to the oestrogenic potential of $17 \beta$-E2 $(100 \%)$, the receptor affinity of $17 \alpha-\mathrm{EE} 2$ is $88.8 \%$, E1 is $9.6 \%, 17 \alpha-\mathrm{E} 2$ is $5.25 \%$, E3 is $0.63 \%$, and BPA is $0.005 \%$ (Coldham et al. 1997). Oestrogenic substances have several adverse effects for animals and human, such as distracting the hormonal system, reducing the efficiency of the immune system, causing developmental disorders, and the most common negative effect is dysfunction of the reproductive system, which can lead to reduced fertility and changes in sexual behaviour (Kumar et al. 2020). Sex drive and responsiveness, gender identification, and sexual preference are all influenced by hormones and therefore by endocrine-disrupting chemicals. (Mhaouty-Kodja et al. 2018; Lopez-Rodriguez et al. 2021).

Our research was conducted at a dairy cattle farm using a slurry management system, focusing on the investigation of the presence of oestrogenic chemicals in the slurry due to intense husbandry. We monitored the changes in the quantity of the oestrogenic substances, the storage effects and treatment procedures over a wide range of time periods for twelve months starting in January 2017. Additionally, we conducted ecotoxicological studies on the same samples using different test organisms (soil bacteria, Daphnia magna, different plant seeds, algae) providing a detailed and complex toxicological study on slurry samples.

\section{Materials and methods}

\subsection{The origin of the investigated samples}

Samples originated from a dairy cattle farm in KomáromEsztergom County, Hungary. The average number of animals at the farm is 1200 , including 600 dairy cattle and 600 dry cows, heifers, and calves. The manure from the barn's individual stalls is regularly rinsed with water and transferred to a storage pool. At specific time intervals, if the pre-pool storage is full, the liquid and the suspended solid parts of this material are separated using a machine called a separator. Separation can be performed by settling tanks or by forced settling with the use of centrifuges. This latter technique allows to reduce the settling time for separation using centrifugal force. The applied device is a vertical decanter centrifuge which in operation separates solids and liquids at the wall with rotations at high speed. The solid particles then conveyed towards the conical end of the structure while the supernatant enters to bowl-shape cylinder (Hjorth et al. 2010). The solid part is treated as bedding manure after further processing, while the liquid part is stored in the pool, stirred continuously with two high-performance stirrers and finally delivered to the cropland. The irrigation period runs from early spring until late October.

In 2017, we sampled two pools in each season. Four sample were taken from the fresh slurry storage pool and four sample from the pool, which is the endpoint of the separation process, where the slurry usually stored for 30 days. Samples were taken each time from the four edges of the pool $(1 \mathrm{~L}$ each) and were combined. In both pools, the slurry was mechanically mixed, therefore samples deemed as homogenous and representative samples. In the spring season, the separator was out of order; consequently, the 30-day material was not separated.

Samples were collected in disposable, sterile polypropylene Falcon tubes, which were free of DNase, RNase, endotoxin and metal, were freezable down to $80{ }^{\circ} \mathrm{C}$ and were resistant to chemicals. Samples were placed in the refrigerator and processed within 4-6 days after sampling.

\subsection{Yeast oestrogen screen for the investigation of oestrogenic effect}

The samples were centrifuged in 50-mL Falcon tubes for $20 \mathrm{~min}$ at a speed of 4200 rotations per minute (rpm) at a constant temperature of $4{ }^{\circ} \mathrm{C}$. Endocrine-disrupting chemicals were extracted from the $30 \mathrm{~mL}$ supernatant using solid-phase micro extraction (SPE). First, the extraction cartridge (Strata $\times 200 \mathrm{mg} / 6 \mathrm{~mL}$ from Phenomenex, USA) was conditioned using a mixture of $8 \mathrm{~mL}$ methanol and $8 \mathrm{~mL}$ water with a 95:5 ratio, completing a regular rinse with technical grade methanol solution. In the second step, $30 \mathrm{~mL}$ of liquid slurry supernatant was passed through the cartridge. In the third step, rinsing was performed with $10 \mathrm{~mL}$ methanol-water $(1: 1)$ and $10 \mathrm{~mL}$ acetone-water (2:1). After a few minutes of drying, the retained components were eluted in $5 \mathrm{~mL}$ methanol. After elution, $200 \mu \mathrm{L}$ 
of sample was dissolved in $1800 \mu \mathrm{l}$ methanol, which was a tenfold dilution. Then, further $50 \times, 100 \times, 500 \times$, $1000 \times, 5000 \times$, and $10000 \times$ dilutions were prepared for yeast testing. Two (2) grams of the sediment (from centrifugation) was mixed with $10 \mathrm{~mL}$ methanol and sonicated for $30 \mathrm{~min}$ at $30^{\circ} \mathrm{C}$ and then centrifuged for $10 \mathrm{~min}$ at $4{ }^{\circ} \mathrm{C}$ at $2000 \mathrm{rpm}$ velocity. The supernatant was further diluted, as in the liquid phase $(10 \times-10000 \times)$, and then used for testing.

As discussed above, our environment is polluted from several sources by substances, that can bind to human oestrogen receptor. The chemical diversity of these substances is high, which makes their analysis very difficult as different analytical methods are required for their detection. Even very detailed analysis of a particular sample, it cannot be completely ruled out that any of the oestrogenic substances remain undetected. This problem is bridged by the methods which detect the oestrogenic substances from the effect side such as the in vitro reporter gene assay, the yeast oestrogen screen (YES). Additionally, it has a number of advantages over other similar detection systems, such as the absence of endogenous steroid hormone receptors and consequent lack of complex interactions between the oestrogen receptor (ER) and other receptors (Routledge and Sumpter 1996; Purvis et al. 1991).

Because of the reasons above, oestrogenic activity of the sample extracts was evaluated using the recombinant yeast strain Saccharomyces cerevisiae BJ3505, according to the protocol ISO 19040-1:2018. The yeast continuously produces the human oestrogen receptor. When the human oestrogen receptor interacts with oestrogen or with oestrogen analogue molecules in the cytoplasm, it is activated. The activated receptor activates the lac $Z$ operon on the plasmid, starting the production of the $\beta$-galactosidase enzyme in proportion to the amount of the oestrogen or oestrogen analogue molecules present in the sample. The activity of the produced $\beta$-galactosidase enzyme was measured using ultraviolet-visible spectroscopy (LabSystems Multiskan MS) at $580 \mathrm{~nm}$, where $\beta$-galactosidase catalyses the hydrolysis of the galactoside analogue chlorophenol red- $\beta$-D-galactopyranoside (CPRG) and converts the yellow-orange CPRG substrate into the red chromophore chlorophenol red, yielding a dark red solution (Routledge and Sumpter 1996; Purvis et al. 1991).

For the analysis of the oestrogenic activity, $10-\mu \mathrm{L}$ aliquots of the sample extract were transferred to the wells of a sterilized 96-well optical flat-bottom microtitre plate (Nunc, Germany), and the solvent was allowed to evaporate until dry. The wells were then supplied with $120 \mu \mathrm{L}$ of the assay medium containing yeast cells, and the covered plates were incubated at $30{ }^{\circ} \mathrm{C}$ in an incubator (PLO-EKO Aparatura) for 1 day. Then, $30 \mu \mathrm{L}$ of each well of the test plate was transferred to a new 96-well plate, and $50 \mu \mathrm{L}$ reaction mixture containing $\mathrm{CPRG}$ and Lyticase was added; the plates were then incubated for one more hour. The colour development was measured at $580 \mathrm{~nm}$, and the turbidity of the yeast cell biomass was read at $620 \mathrm{~nm}$ (LabSystems Multiskan MS).

In parallel, each plate contained the concentrations of the standard E2 $\left(0.66 \mathrm{ng} \mathrm{L^{-1 }}\right.$ to $\left.500 \mathrm{ng} \mathrm{L}^{-1}\right)$ as a positive control and negative control wells consisting of either methanol alone or processed distilled water, as well as blank wells containing no organism but treated in the same way as the other replicates in the sample. Each test substance was analysed four times.

Based on the results (initial and final yeast cell density and colour change at $580 \mathrm{~nm}$ ), the relative growth $(620 \mathrm{~nm})$ to assess the potential toxic effects of the sample and the average corrected absorbance $(580 \mathrm{~nm})$ were calculated using Microsoft Excel. Subsequent statistical evaluation and concentration-response curves were constructed using a Web-based tool (www.elisaanalysis.com). The standard curve calibration was performed using a 4- or 5-parameter logistic regression model (Findlay and Dillard 2007). For the determination of E2-oestradiol equivalents (EEQ), the corrected absorbance of the sample extracts was interpolated in the linear range of the corresponding oestradiol standard curve (Hong 2012).

\subsection{Toxicological tests}

Ecotoxicological tests characterize potential adverse effects that a slurry causes to a terrestrial or an aquatic receptor. For the toxicological evaluation of the slurry 4 test organisms were selected paying attention to their different place in the phylogenetic tree. As a result, 2 terrestrial (bacteria and plant seeds) and 2 aquatic (algae and crustacean) receptor were chosen. Relative chemical hazards to terrestrial organisms do not necessarily follow the same patterns as that seen with aquatic organisms, necessitating separate testing and assessment schemes. Monetary and ethical considerations make difficult to conduct toxicity tests on vertebrates ("National Research Council" 2014; Parry 1998).

Each toxicological test was performed on undiluted samples and on $10 \times, 50 \times, 100 \times$ and $500 \times$ dilutions. The determination of these dilution factors was calculated from earlier oestrogen content studies. Samples for the toxicology tests were collected only in the summer period, not in all seasons, since the liquid slurry is mainly applied in the summer period during row-crop cultivation and irrigation purposes.

The oestrogen content (EEQ) of the investigated samples were $390 \pm 40 \mathrm{ng} \mathrm{L}^{-1}$ before separation and $3 \pm 0.3 \mathrm{ng} \mathrm{L}^{-1}$ after separation determined by yeast screen. The slurry tested by us can be said to be average in 
terms of nutrient content. Before separation the characteristics of the slurry were as follows: dry matter content: $20 \mathrm{~g} \mathrm{~L}^{-1}$; pH: 7.15, total nitrogen content: $0.98 \mathrm{~g} \mathrm{~L}^{-1}$; ammonium-nitrogen: $\quad 0.25 \mathrm{~g} \mathrm{~L}^{-1}$; nitrite-nitrate-nitrogen: $<0.50 \mathrm{~g} \mathrm{~L}^{-1}$; phosphorus: $0.23 \mathrm{~g} \mathrm{~L}^{-1}$; potassium: $0.63 \mathrm{~g} \mathrm{~L}^{-1}$. After separation the contents were modified as follows: dry matter content: $0.9 \mathrm{~g} \mathrm{~L}^{-1}$; $\mathrm{pH}$ : 7.14; total nitrogen content: $0.39 \mathrm{~g} \mathrm{~L}^{-1}$; ammonium-nitrogen: $0.07 \mathrm{~g} \mathrm{~L}^{-1}$; nitrite-nitrate-nitrogen: $<0.30 \mathrm{~g} \mathrm{~L}^{-1}$; phosphorus: $0.13 \mathrm{~g} \mathrm{~L}^{-1}$; potassium: $0.41 \mathrm{~g} \mathrm{~L}^{-1}$. As it is visible from the data the separator reduced the dry matter content by $95.5 \%$, total nitrogen content by $60.2 \%$, ammoniumnitrogen by $72.0 \%$, nitrite-nitrate nitrogen by $40.0 \%$, phosphorus by $43.5 \%$ and potassium by $35.0 \%$ and $\mathrm{pH}$ did not change. Anti-inflammatory drugs such as marbofloxacin (1700 mg per month), ketoprofen (2300 mg per month), prednisoline (200 mg per month), antibiotics such as udder infusions, ampicillin (2500 mg per month), cloxacillin (200 mg per month), cefquinom (100 mg per month), novobiocin (150 mg per month), benzylpenicillin procaine (100 $\mathrm{mg}$ per month), dihydrostreptomycin (100 mg per month), neomycin (150 mg per month), ceftiofur $(6000 \mathrm{mg}$ per month), oxytetracycline $(12,000 \mathrm{mg}$ per month) and sex-inducing and synchronizing products such as cloprostenol (22 mg per month), prostaglandin F2 alpha (7100 mg per month), D-Phe6-Gonadorelin (180 mg per month) were used regularly at the investigated farm. Furthermore, parlour acid- (30-32\% hydrochloric acid, 200 L per month, 20\% phosphoric acid, $100 \mathrm{~L}$ per month) and/ or alkaline-based (15\% sodium hypochlorite, $500 \mathrm{~L}$ per month) chemicals also applied for the disinfection of milking cows and trotter care products. These chemicals also appear in slurry samples.

\subsubsection{Azotobacter agile and Pseudomonas fluorescence soil toxicity test}

Azotobacter agile and Pseudomonas fluorescence test organisms are contamination-sensitive soil bacteria (Gruiz et al. 2001). These bacteria have the ability to fix molecular nitrogen and therefore increase soil fertility and stimulate plant growth. Azotobacter species are widely used in agriculture, particularly in nitrogen biofertilizers (Neeru 2000). Pseudomonas fluorescence are commensal rhizosphere bacteria that help plants attain key nutrients, degrade pollutants, and suppress pathogens via antibiotic production. Plants provide nutrients for these organisms and shelter them against stressful environments (Paulsen et al. 2005).

The aim of these tests was to detect any growth inhibition of these soil bacteria. The agrochemical properties of our reference test soil were as follows: humus content $1.25 \mathrm{~m} \mathrm{~m}^{-1} \%$, binding (KA) 31 , which corresponds to sandy loam soil, $\mathrm{pH}_{(\mathrm{KCl})} 7.2$ neutral $\mathrm{pH}$, carbonated lime content $4.2 \mathrm{~m} \mathrm{~m}^{-1} \%$, weakly calcareous, nitrite-nitrate nitrogen $25 \mathrm{mg} \mathrm{kg}^{-1}$, phosphorus $110 \mathrm{mg} \mathrm{kg}^{-1}$, and potassium $140 \mathrm{mg} \mathrm{kg}^{-1}$. First, the test soil was air-dried on a flat surface, and the water holding capacity was determined as follows: $90 \mathrm{~g}$ soil sample was mixed with $50 \mathrm{~mL}$ distilled water in a graduated cylinder and was allowed to stand for $24 \mathrm{~h}$ until the soil-water mixture reached equilibrium. A microsieve cylinder and a micropipette were used to remove the water from the surface of the soil and transfer the retrieved water $(\mathrm{S})$ into a graduated cylinder. The volume of water (Vsat) needed for complete hydration of the test soil $\left(90 \mathrm{~cm}^{3}\right)$ was calculated using the following formula: $V$ sat $=50-\mathrm{S}$. During the test, $210 \mathrm{~cm}^{3}$ test soil was mixed with $65 \mathrm{~mL}$ slurry $(V$ sat $=28 \mathrm{ml})$. Soil extraction was performed using high-purity water $(100 \mathrm{~mL}$ water was added to $10 \mathrm{~g}$ soil), and dilution series were prepared $(2 \times, 5 \times, 10 \times, 25 \times, 50 \times, 100 \times)$.

Tests were performed in microtitre plates in three repetitions, in which each well contained $0.2 \mathrm{~cm}^{3}$ modified Fjodor Durov broth containing triphenyltetrazolium chloride (TTC), bacterial culture and $0.05 \mathrm{~cm}^{3}$ sample. Positive $(10 \mathrm{mg} / \mathrm{L} \mathrm{Cu}$ solution) and negative (high-purity water, 'Herco') controls were also included. Samples were incubated for $48 \mathrm{~h}$ at $28{ }^{\circ} \mathrm{C}$ (Pol_Eko_Aparatura 4.81 Incubator). The bacterial activity is visible when the colourless TTC changes into red triphenyltetrazolium formazan (TTF). Red indicates no growth inhibition $(+)$, pale red indicates medium growth inhibition $( \pm)$ and colourless broth indicates total growth inhibition (-) (MSZ 21,978:30).

\subsubsection{Daphnia acute immobilization test}

Daphnia magna Straus juveniles younger than $24 \mathrm{~h}$ old are sensitive to environmental changes, including chemicals. Newborn crustacea were separated from the culture stock of the National Public Health Center, Budapest and were used for the investigations. Tests were performed in 2 replicates, and 10-10 juveniles were placed in $50 \mathrm{~mL}$ test medium and incubated for $48 \mathrm{~h}$ at $22{ }^{\circ} \mathrm{C}$ in an air-conditioned room. The immobilization was read every $24 \mathrm{~h}$. Quality controlled tap (drinking) water, aerated for 7 days, was used as a negative control and for dilution. Dissolved oxygen (DO) and $\mathrm{pH}$ were measured at the beginning and at the end of the test in order to control the testing circumstances ( $\mathrm{pH}: \quad 7.2-9.4$ and $\mathrm{DO}>2 \mathrm{mg} \mathrm{L}^{-1}$ ). The Daphnia acute immobilization test is valid if the number of immobile animals is less than $10 \%$ in the negative control and the sensitivity of the Daphnia magna culture against potassium dichromate reference solution is in the range of 0.6-2.1 $\mathrm{mg} \mathrm{L}^{-1} \mathrm{EC}_{50 \mathrm{i}}(24 \mathrm{~h}$ ) (ISO 6341). 


\subsubsection{Algae growth inhibition test}

The aim of this test was to detect cell growth inhibition of the green algae Pseudokirchneriella subcapitata (Korshikov) F. Hindák (origin: Culture Collection of Algae and Protozoa, UK; CCAP 278/4) in different dilutions of the slurry. Fifty millilitre samples were tested in Erlenmeyer flasks, and each dilution was analysed in three replicates. Samples were spiked using $800 \mu \mathrm{L}$ Pseudokirchneriella subcapitata cell culture in the phase of exponential growth $\left(10^{5}\right.$ cell $\left.\mathrm{mL}^{-1}\right)$. The starting algae cell density was determined using a Burker counting chamber (Hirschmann EM Techcolor, Tiefe Depth Profondeur $0.0025 \mathrm{~mm}^{2}$; $0.100 \mathrm{~mm}$ ) and an optical microscope (Leica Microsystems, Leica DM 2500). The algae cell optical density at $750 \mathrm{~nm}$ was determined using a spectrophotometer (Metertech Inc., SP-830 Plus) and the starting optical density was 0.02 , which corresponds to a 0 -h OD. Negative control (Zhender- 8 broth) and blank flasks that contained no organism but were treated in the same way as the other replicates in the sample were also included. Samples were incubated for $72 \mathrm{~h}$ with continuous shaking (speed of $100 \mathrm{rpm}$ ) and lighting $\left(8,500 \mathrm{l} \times\right.$ ) at $24{ }^{\circ} \mathrm{C}$ (Witeg Labourtechnik GmbH, Witeg WIS-RL Shaking Incubator). On the last day, cell density-based growth inhibition (optical density at $750 \mathrm{~nm}$ ) was measured using a spectrophotometer (Metertech Inc., SP-830 Plus) calibrated to the blank solutions. This toxicity test is regarded as valid if the average daily algae cell growth is at least $1.4 \times$ in the negative control, the value of $\mathrm{pH}$ does not change more than 1.5 units, the coefficient of variation of the negative control's growth rate is not more than $5 \%$ and the sensitivity of the Pseudokirchneriella subcapitata culture against potassium dichromate reference solution is within the range of $1.19 \pm 0.27 \mathrm{mg} \mathrm{L}^{-1}$ (ISO 8692).

\subsubsection{Phytotoxkit microbiotest}

A Phytotoxkit microbiotest (MicroBioTests Inc., TK62 L Phytotoxkit) was used to test agricultural seed germination and the growth of young roots. Both monocotyledonous (Sorghum saccharatum; Triticosecale) and dicotyledonous (Sinapis alba; Lepidium sativum; Fagopyrum esculentum) plants were selected for testing. First, the test soil was airdried on a flat surface, and the water holding capacity was determined as described above. During the test, $90 \mathrm{~cm}^{3}$ test soil was mixed with $30 \mathrm{~mL}$ slurry or with its dilutions. Ten seeds per plate were positioned at equal distance near the middle ridge of the test plate; the plates were then covered and placed vertically in a holder box and incubated at $25{ }^{\circ} \mathrm{C}$ for 3 days (Pol_Eko_Aparatura 4.81 Incubator). After the incubation time, the lengths of the roots were measured, and the germination rate and growth inhibition were calculated as percentages compared to the control sample. For control plates, distilled water was used. The seedling growth test is regarded as valid if the germination average is at least $70 \%$, and the average length of the roots in the control is at least $30 \mathrm{~mm}$ (MicroBioTest 2018).

\subsubsection{Data analysis}

A relationship between the observed effects on immobility and growth rates to the exposure concentrations were established and the US Environmental Protection Agency Probit Program Ver 1.5 was used to calculate the ED (effective dilution) values and their $95 \%$ confidence intervals for this study (EPA 1999). Median effect dilution $\left(E_{50}\right)$ and effective dilution at $10 \%$ inhibition $\left(\mathrm{ED}_{10}\right)$ were calculated for Daphnia immobilization test, bacteria and algae test, respectively. The $\mathrm{ED}_{50}$ refers to the dilution of a substance that induces a response halfway between the baseline and maximum and $\mathrm{ED}_{10}$ refers to the dilution that causes the measured effect in $10 \%$ of organisms after the exposure time. In case of phytotoxkit microbiotest values representing a no-effect level (NOEL) were also given. NOEL is the highest dose or exposure level of the slurry that produces no noticeable (observable) toxic effect on tested plants (ISO 8692, ISO 6341, MicroBioTest 2018).

\section{Results}

\subsection{YES test}

During the studies, the determination of the content of the oestrogenic substances in our samples was performed in 7 different dilutions $(10 \times, 50 \times, 100 \times, 500 \times$, $1,000 \times, 5,000 \times, 10,000 \times)$. The highest dilution at which all (16) samples gave negative results was $10,000 \times$. Testing of the samples started at a concentration close to the original concentration, tenfold $(10 \times)$. When the $10 \times$ dilution gave a negative result, the concentrated samples were tested (Table 1). In pharmacology, an agonist is a substance that mimics the action of a hormone by binding to the same receptor, causing a biological response, while an antagonist does not cause a response. As the processed samples may contain a very wide range of chemical substances at various concentrations, increasing the dilution may dilute certain antagonist compounds that bind to the desired human oestrogen receptor (Lehel and Laczay 2011). We assume that this is the explanation for the phenomenon that different dilutions of samples gave different results. Therefore, the average values were used for further calculations considering the deviations, respectively, (Table 1). 


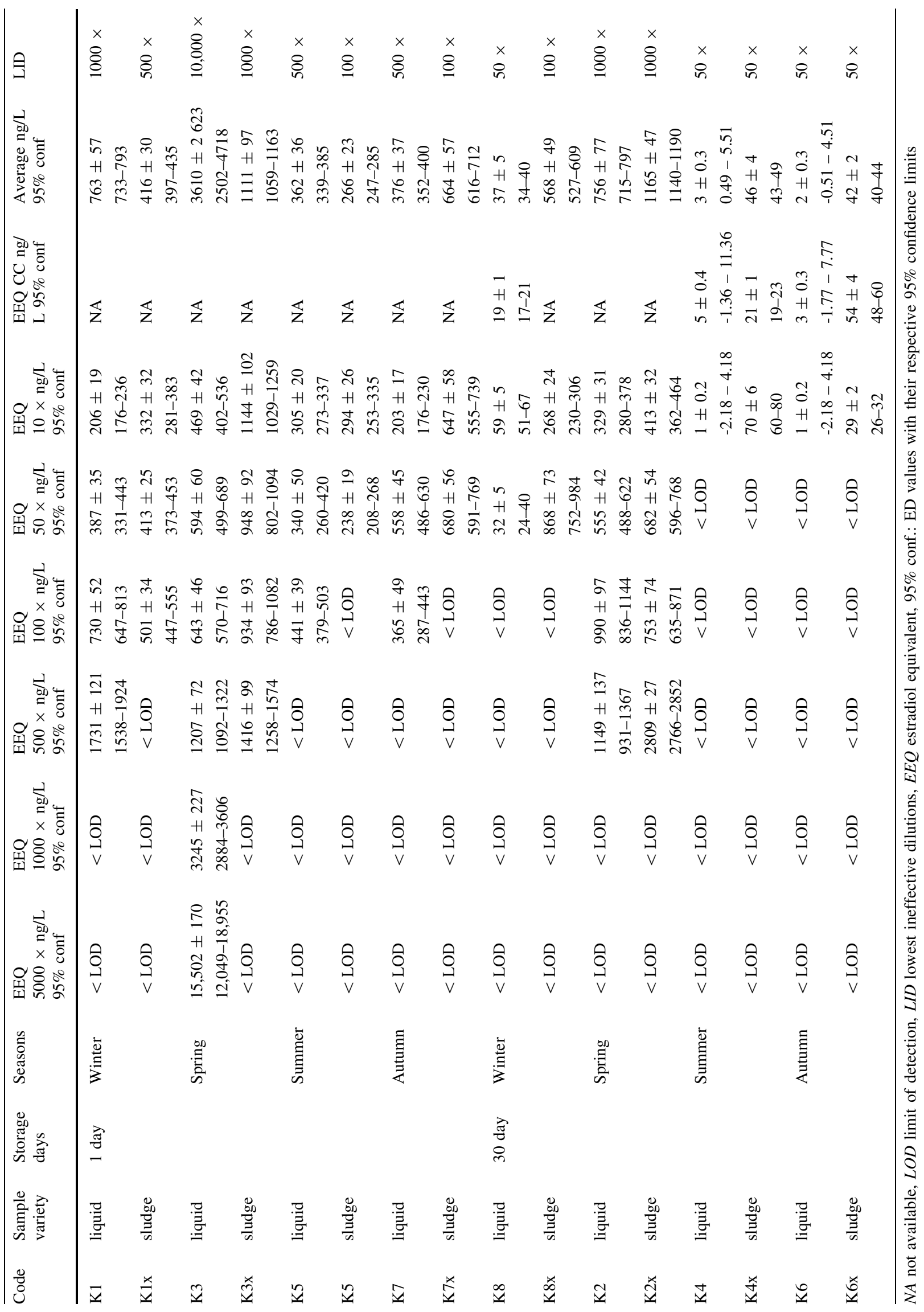




\subsubsection{One-day samples without separator}

The autumn and summer supernatant fraction of the centrifuged liquid slurry contained oestrogen-derivative (ED) materials at the lowest concentrations (558 \pm 45 and $441 \pm 39 \mathrm{ng} \mathrm{\textrm {L } ^ { - 1 }}$ ). Similarly, in the sediment phase, the summer samples showed the lowest oestrogenic compound levels (294 $\left.\pm 26 \mathrm{ng} \mathrm{L}^{-1}\right)$. The values of the spring samples (separator was out of order) were extremely high compared with the samples from other seasons (liquid $15.502 \pm 2.170 \mathrm{ng} \mathrm{L}^{-1}, \quad$ sediment $1.416 \pm 99 \mathrm{ng} \mathrm{L}^{-1}$ ) (Fig. 1).

\subsubsection{0 days after separator}

Similarly, for the one-day samples, the autumn and summer fractions of the centrifuged liquid slurry showed the lowest ED concentration $\left(1 \pm 0.2-5 \pm 0.4 \mathrm{ng} \mathrm{L}^{-1}\right)$, while higher concentrations were observed in the spring samples $\left(1.149 \pm 137 \mathrm{ng} \mathrm{L}^{-1}\right)$. In the sediment, the oestrogenic compound level in the autumn samples was the lowest (54 $\pm 4 \mathrm{ng} \mathrm{L}^{-1}$ ), while in the spring samples (separator was out of order) were the highest $\left(2.809 \pm 27 \mathrm{ng} \mathrm{L}^{-1}\right)$. The spring values are also extremely high in this case (Fig. 2).

\subsection{Toxicological tests}

\subsubsection{One-day samples without separator}

The two soil microbiology tests and the Daphnia acute immobilization test were considered valid. The percentage Daphnia immobilization of the controls was less than $10 \%$ $(0 \%)$, and the $24-\mathrm{h} \mathrm{EC}_{50}$ of the potassium dichromate was within the range of $0.6 \mathrm{mg} \mathrm{L}^{-1}$ to $2.1 \mathrm{mg} \mathrm{L}^{-1}$
(= $\left.1.56 \mathrm{mg} \mathrm{L}^{-1}\right)$. In the soil toxicity tests, the positive control (10 $\mathrm{mg} \mathrm{L}^{-1}$ copper solution) showed total inhibition. These three tests did not show any negative effect of the slurry on the test organisms.

The algae growth inhibition tests were also considered valid. The biomass in the control after the 72-h test period was $27 \times$, and the $\mathrm{pH}$ in the different dilutions did not change by more than 1.5 during the test period. Preliminary testing using the algae growth inhibition test showed that the dilutions used $(10 \times, 50 \times, 100 \times$ and $500 \times)$ were not suitable for further calculations, because the differences between the undiluted, original sample and the next dilution $(10 \times)$ were exceptionally high. The growth inhibition in the undiluted liquid slurry was $93 \%$, while in the $10 \times$ dilution, it was only $5 \%$ (considered as no real inhibition). For the reasons above, $2 \times, 4 \times, 6 \times$, and $8 \times$ dilutions were further tested. In the undiluted slurry, there was $93 \%$ inhibition, the $4 \times$ dilution showed $67 \%$ inhibition and the $10 \times$ dilution gave similar results as those of the control sample. Calculated $\mathrm{ED}_{10}$ is at $9.3 \times$ dilution, $95 \%$ lower confidence limit 37.7, 95\% upper confidence limit 6.1. Calculated $\mathrm{ED}_{50}$ is at $4.1 \times$ dilution, $95 \%$ lower confidence limit 6.3, 95\% upper confidence limit 2.2.

Based on the Phytotoxkit microbiotest, all of the seeds in the control reached the limit root length $(30 \mathrm{~mm})$, and the germination rate was more than $70 \%$; thus, the tests were considered valid. Using undiluted slurry, 14-45\% inhibition was measured for Sinapis, Lepidium, Fagopyrum and Triticosecale. The $10 \times$ dilutions gave almost the same results as the undiluted sample, but the $50 \times$ dilutions in Sinapis, Lepidium, and Fagopyrum and the $100 \times$ dilutions in Triticosecale gave negative results. The Sorghum seed was not sensitive, and the undiluted slurry
Fig. 1 Seasonal changes of EEQ-s of 1-day slurry samples in the liquid and suspended solid phase

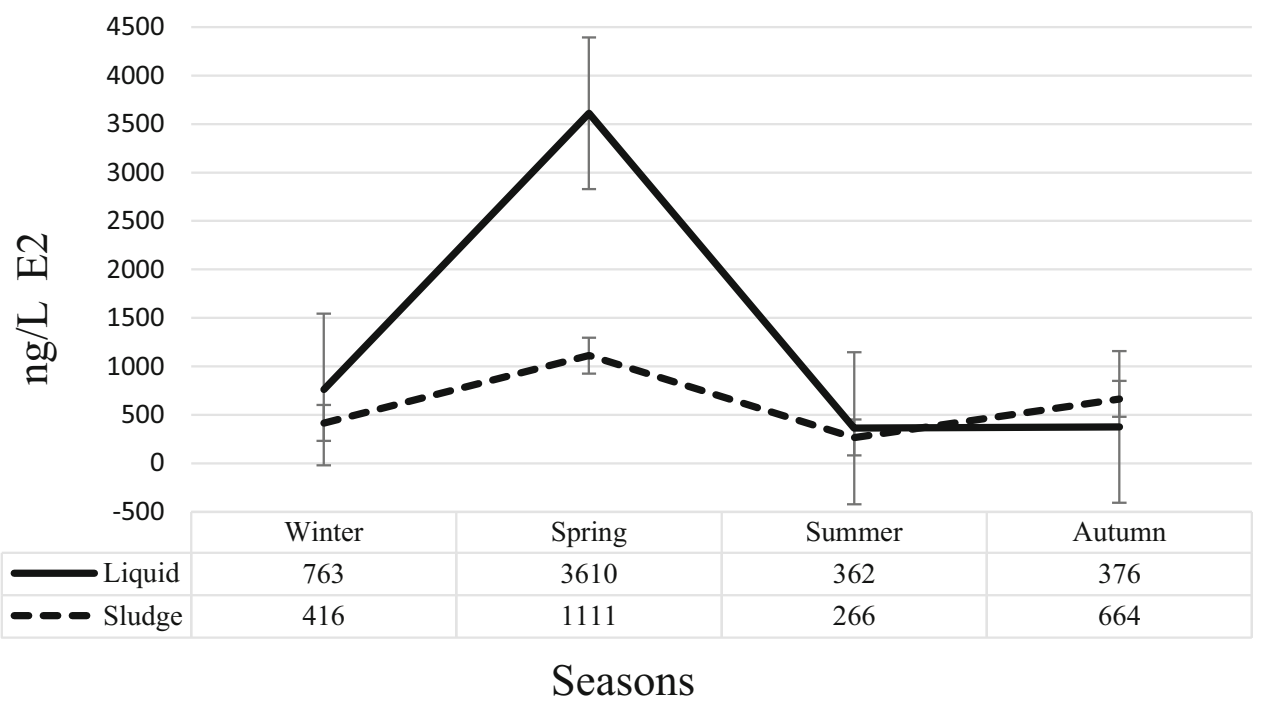


Fig. 2 Seasonal changes of EEQ-s of 30-day slurry samples in the liquid and suspended solid phase

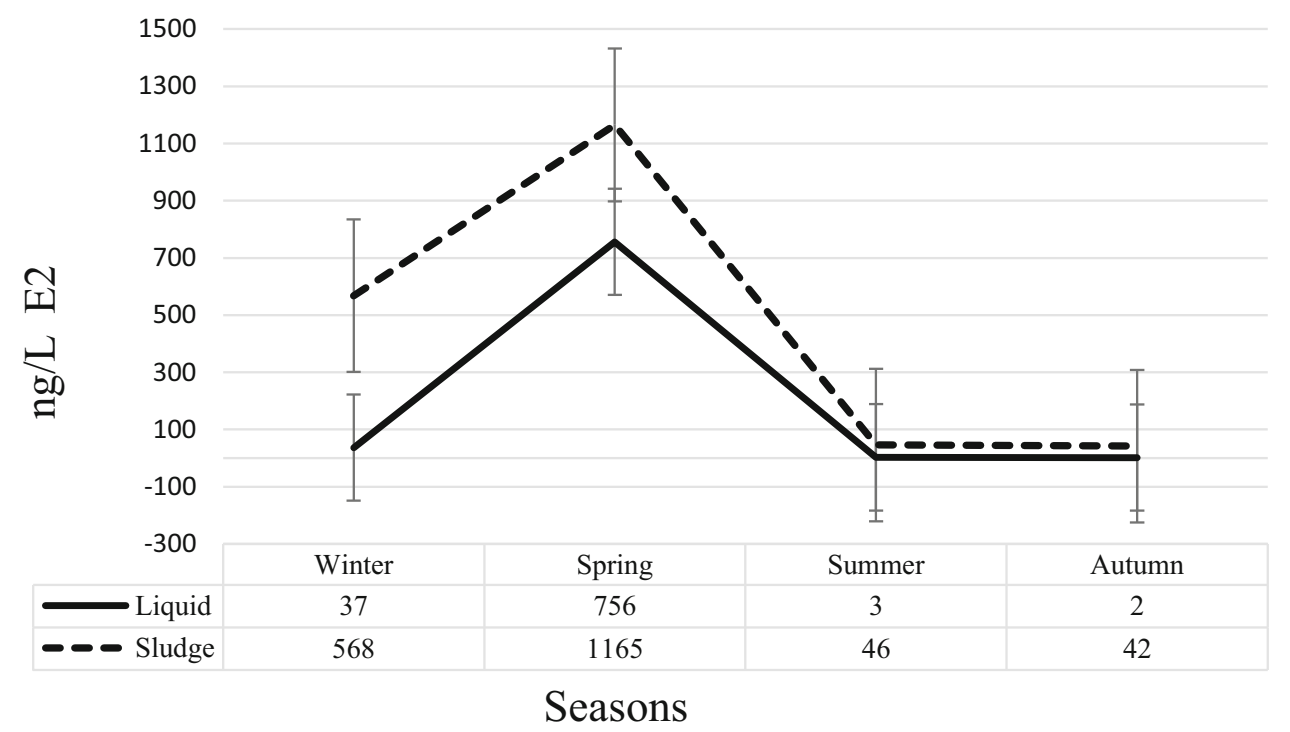

stimulated the growth of this plant (30\% stimulation) (Table 2).

\subsubsection{0-day samples after separator}

The Daphnia acute immobilization test and the two soil microbiology tests were considered valid, as described above, and did not show any negative effects of slurry on the test organisms.

The algae growth inhibition test using undiluted or diluted slurry gave negative results. The relative algae cell growth was $97.5 \%$ in undiluted slurry, and we consider this to be under $10 \%$ inhibition $\left(\mathrm{ED}_{10}\right)$, which is the non-observed effect level (NOEL). We measured $2.5 \%$ inhibition and $3-16 \%$ stimulation in the dilution series. The $16 \%$ stimulation had a positive effect on algae growth.

In the case of the Phytotoxkit microbiotest, all of the seed tests were considered valid, as described above. Sorghum showed stimulation in each dilution, and the maximum stimulation was $60 \%$ in the undiluted sample. Lepidium and Sinapis showed 53\% and 18\% inhibition at a $10 \times$ dilution, respectively, but all other dilutions had no positive or negative effect on germination. The growth of other plants (Fagopyrum, Triticosecale) was near the control in each dilution (Table 2).

\section{Discussion}

\subsection{Oestrogenic substance content}

In the case of the 30-day samples, it can clearly be seen that $71-95 \%$ of the overall oestrogenic substance is absorbed to the suspended solid phase. During storage, the solid phase absorbed the ED components, and the absorbed amount exceeded that of the liquid phase. Sorption experiments with pig slurry separation technique state that the separation of the liquid slurry enhance the infiltration of the oestrogen compounds to the soil matrix, therefore the sedimentation process envolve E2 reacting with the carbon content of the crude fibre fraction of the slurry. By physical separation (sedimentation and centrifugation process) of the liquid matter, $50-75 \%$ of E2 can be absorbed in solid particles (Mostofa et al. 2012). The oestrogens are retained onto sludge due to their high adsorption (Louros et al. 2019). A separator, therefore, can highly decrease the oestrogenic effect of the liquid slurry, not only making the emission of the slurry easier but also delivering a safer substance into the environment. This conclusion is also supported by the results of the 30-day spring samples when the separator was out of order, and the oestrogenic concentration of untreated samples showed an extremely high level. To clean sewage or manure from oestrogens physical treatments such as coagulation, activated carbon and membrane separation or chemical treatments identical to advanced oxidation processes (AOPs), like ozone, ultraviolet degradation, manganese oxide, ferrate, chlorination, titanium dioxide, fenton, sonolysis, can be used. Although these treatment techniques will surely reduce the oestrogens, they represent a large financial cost in addition to environmental impact caused by increasing energy consumption and $\mathrm{CO}_{2}$ emission (Nazari and Suja 2016).

In nitrite-sensitive areas, the liquid slurry emission limit is approximately $180 \mathrm{~m}^{3}$ per ha (considering the $170 \mathrm{~kg}$ per ha approved limit for nitrogen), as determined by Decree 27/2006 (II.7). If we calculate the average amounts of oestrogen content of the liquid and the solid phases of the slurry (for the 1-day samples; liquid: $4560 \mathrm{ng} \mathrm{L}^{-1}$ and 


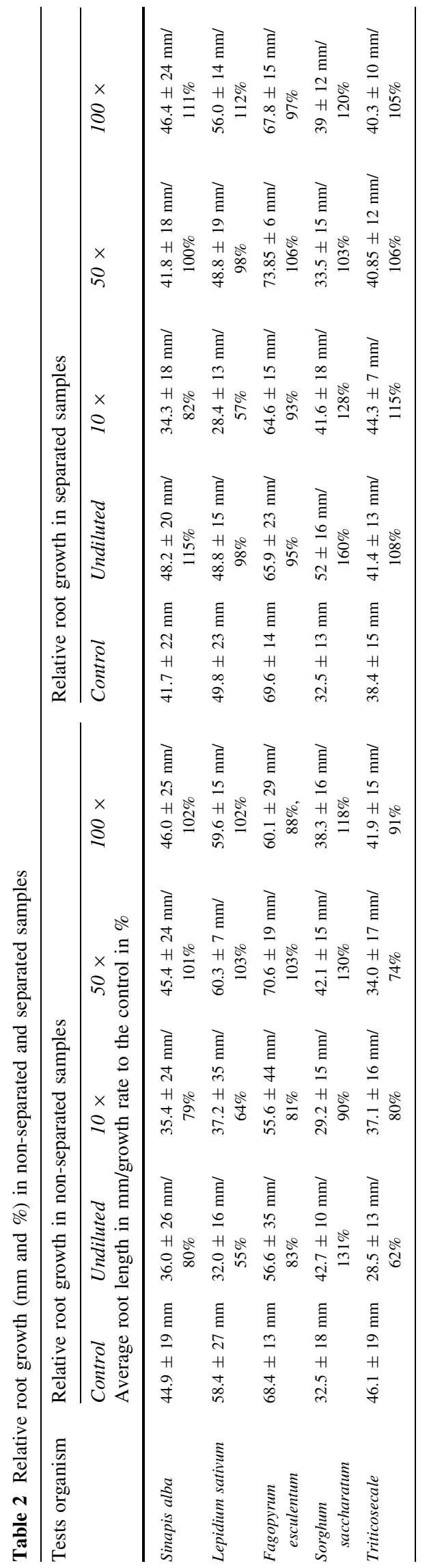

solid: $723 \mathrm{ng} \mathrm{L}^{-1}$ for the 30-day samples; liquid: $22 \mathrm{ng} \mathrm{L}^{-1}$ and solid $332 \mathrm{ng} \mathrm{L}^{-1}$ ) and apply it for $180 \mathrm{~m}^{3}$, and we consider that the solid sediment content of the slurry is $15 \mathrm{~g} \mathrm{~L}^{-1}$, then we can obtain the following results for EDC (endocrine-disrupting chemical) emission: without a separator is $0.81 \mathrm{~g} / \mathrm{ha}(810 \mathrm{mg} / \mathrm{ha})$ and using a separator is $0.005 \mathrm{~g} / \mathrm{ha}(5 \mathrm{mg} / \mathrm{ha})$. Therefore, without the use of a separator, we emitted approximately 162 times more EDC into the environment. The liquid slurry was applied in the early spring period before sowing and in the summer period during row-crop cultivation and irrigation purposes.

Research shows, that approximately $90 \%$ of the oestrogen sources in the environment are derived from livestock waste. Primary sources include direct discharge, land-use of manure, and runoff containing oestrogenic compounds from CAFOs (Concentrated Animal Feeding Operations) (Liu et al. 2018). Although different oestrogens are specific to different livestock species. Cattle (Bos taurus) excreting more than $90 \%$ of oestrogens as $17 \alpha$-E2, $17 \beta-\mathrm{E} 2$, and $\mathrm{E} 1$ as free and conjugated metabolites. However, $17 \alpha$-E2 barely discovered in the excreta of swine (Sus scrofa) or poultry (Gallus domesticus) (Hanselman et al. 2003). Wei et al. examined four oestrogens collected from 24 dairy and beef farms located in northeast China. The average concentrations of $17 \alpha$-E2, $17 \beta$-E2 and E1 in dairy faeces were 194.6, 104.4, and $262 \mu \mathrm{g} \mathrm{kg}^{-1}$, respectively. The mean contents of $17 \alpha$-E2, $17 \beta$-E2 and E1 in the beef waste were 104.5, 67.7 and $216.4 \mu \mathrm{g} \mathrm{kg}^{-1}$, respectively. E3 was below the detection limit in all samples (Wei et al. 2011). In the Swiss study of (Rechsteiner et al. 2020) the mean concentrations of cattle slurry were: $861 \pm 367,138 \pm 126,160 \pm 205$, and $397 \pm 411 \mathrm{ng} / \mathrm{L}$ for $17 \alpha$-E2, $17 \beta$-E2, E3 and E1, respectively.

Lee et al. have indicated that oestrogens from manure and cropland fertilized with animal waste pose a serious threat to the surrounding groundwater and surface waters (Lee et al. 2007).

Oestrogen contamination is a worrisome problem due to the well-known effects of oestrogen on human and animal health (Bilal et al. 2021; Bai et al.2019; Jiang, Colazo, and Serpe 2018; Pignotti et al. 2017; Biswas et al. 2013) and on plant growth and development (Schröder et al. 2007; Janeczko and Skoczowski 2005). EDCs can be taken up by plants through active or passive processes, which mostly depend on the characteristics of the compounds and the plants (Chen et al. 2021). Based on the study by Lu et al. (2013) steroidal oestrogens were tested in fruits and vegetables obtained from local markets in Fort Pierce, Fl, USA. Oestrogens were found in the vegetables (lettuce, tomato, pumpkin, potato, carrot), and in the fruits (apple, strawberry, citrus), especially in lettuce, where the $17 \beta$-E2 was 1.26 to $3.09 \mu \mathrm{g} \mathrm{kg}^{-1}$. The toxic level for daily intake (ADI) of $17 \beta-\mathrm{E} 2$ for a $60 \mathrm{~kg}$ adult is $3.0 \mu \mathrm{g} / \mathrm{day}$, according 
to the FAO/WHO Expert Committee on Food Additives (JECFA) (Lu et al. 2013). Certain plants can absorb contaminants from their environment without any negative impact on their development. This mechanism is called phytoextraction. We know many plant species that have adapted to heavy metals (Abhilash et al. 2016), but unfortunately we have little information on plants that are capable of oestrogen accumulation (Chen et al. 2021; Goyal et al. 2020; Adeel et al. 2017). Continuous flow tests with wastewater show that algae and duckweed (Lemna minor) play a key role in oestrogen removal (Shi et al. 2010). Narrowleaf willow (Salix exigua) and thale cress (Arabidopsis thaliana) are also capable to take up oestrogens (Franks 2006). In a hydroponic study in Japan, hundreds of different plants were examined in the presence of oestrogenic substances, but only the common purslane (Portulaca oleracea) was the only effective phytoremediator. It removed phenol-containing chemicals, including 17ß-E2, within $24 \mathrm{~h}$ (Imai et al. 2007). Potato (Solanum tuberosum) root growth and tuber size were reduced by oestrogen (17 $\beta$-E2) (Brown 2006) while growth of maize (Zea mays) seedlings was inhibited by $10 \mathrm{mg} \mathrm{L}^{-1}$ concentration and the concentration of $0.1 \mathrm{mg} \mathrm{L}^{-1}$ acted as growth stimulator (Bowlin 2014). Experiments with maize (Zea mays) have shown that synthetic and natural oestrogens appear in the roots of maize, but only $17 \beta$-E2 has also been detected in the stem (Card et al. 2012). In mungbean (Vigna radiata) (Guan and Roddick 1988) and chickpeas (Cicer arietinum) (Erdal and Dumlupinar 2011), E1 and E2 showed increased germination and vegetative growth at low $(0.1 \mu \mathrm{M})$ concentrations, but inhibited development at high $(60 \mu \mathrm{M})$ concentration. In the case of lentil (Lens culinaris), $17 \beta$-E2 treatment resulted in increased growth and better germination tolerance for cadmium and copper stress (Chaoui and El Ferjani 2013). It should be mentioned that xenoestrogens are also able to interfere with phytoestrogens, which regulate signal transduction between legume plants and the nitrogen-collecting Rhizobium bacteria living in symbiosis with the plant on their root tubers (Fox 2004). Even several researches were conducted, further ones are needed to determine whether plants used for food can uptake oestrogen from the soil through passive and active processes.

\subsection{Toxicological effects}

Except for the plant Sorghum, each seed showed approximately $25 \%$ germination inhibition in unseparated undiluted slurry. The results of the diluted samples showed that none of the dilutions gave more than $50 \%$ inhibition (10-45.2\%). Considering a wastewater, this is a good outcome, but in agricultural practice, farmers aim to use slurry as irrigation water to produce larger crops without any disadvantage to the plants; moreover, the nutrient content of the slurry is supposed to stimulate plant growth. Except for Sorghum, there was no stimulation in the four other seeds (Figs. 3, 4).

The Fagopyrum, Triticosecale, Lepidium and Sinapis seed root lengths irrigated with the separated slurry did not show any difference from the seeds in the control plates. Only the Sorghum seed produced stimulation in the test, which was greater than the previous outcome (from 30 to $60 \%$ ) when it was irrigated without the slurry separation technology (Figs. 3, 4). Based on the results above, we determined the no observable effect levels (NOEL) for each seed irrigated with the slurry processed using
Fig. 3 Algae cell growth (\%) in different slurry dilutions in nonseparated and in separated samples. Sludge is separated from the mixed liquor suspended solids in separated samples

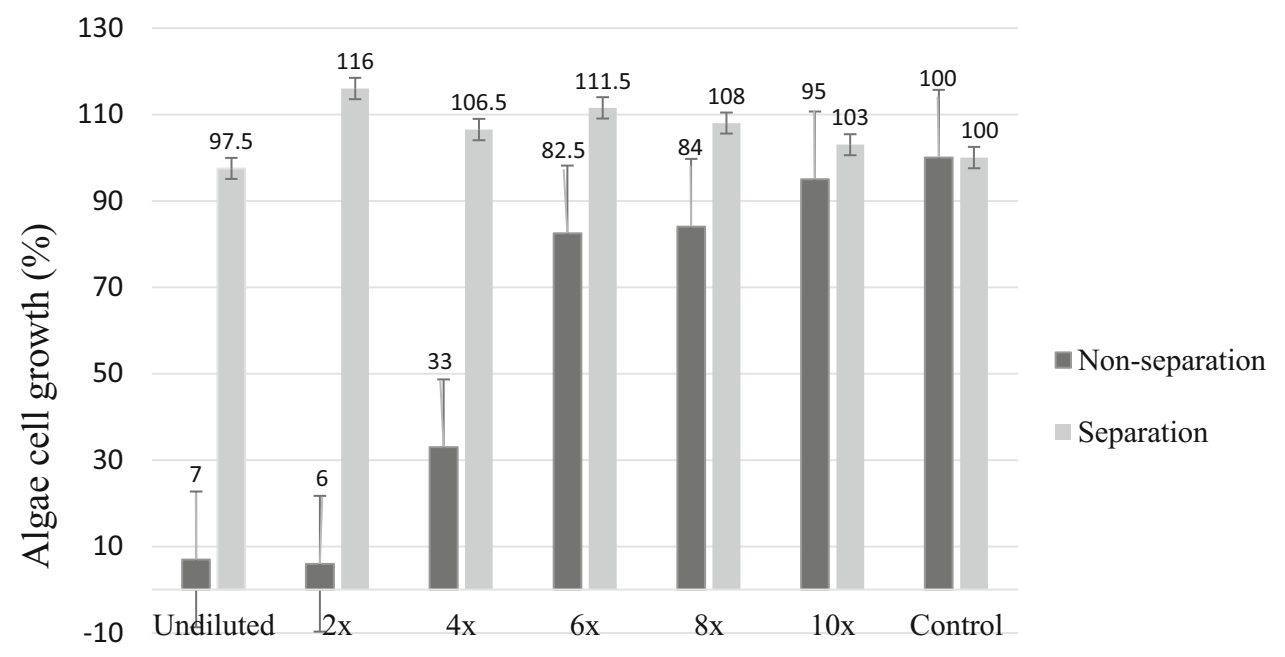

$-30$ 

rate of different seeds $(\%)$ in undiluted slurry in nonseparated and in separated samples. Sludge is separated from the mixed liquor suspended solids in separated samples
Fig. 4 Relative germination

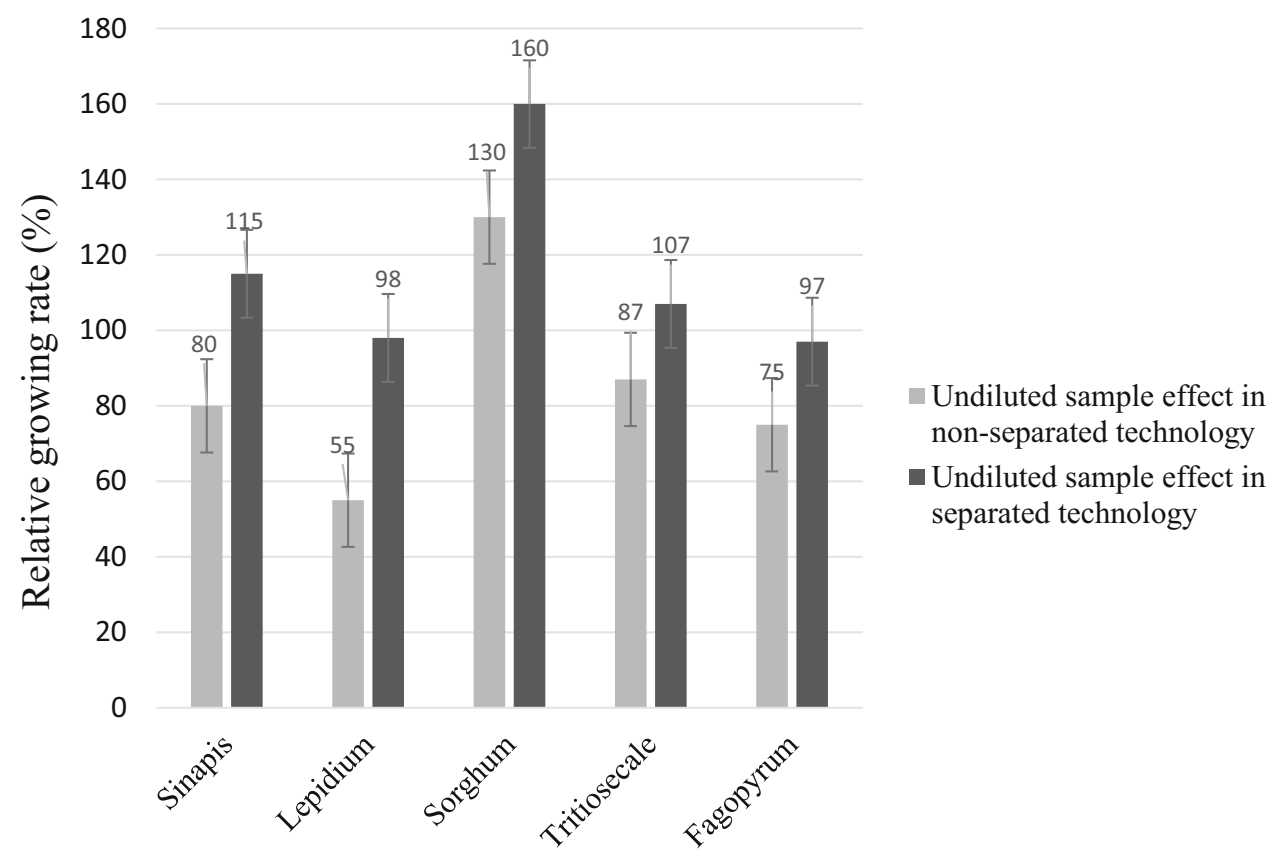

Type of seeds

Fig. 5 NOEL (no observed effect level) values are shown in non-separated and in separated samples, which is the highest dilution of the slurry that produces no noticeable toxic effect on tested seeds. Sludge is separated from the mixed liquor suspended solids in separated samples

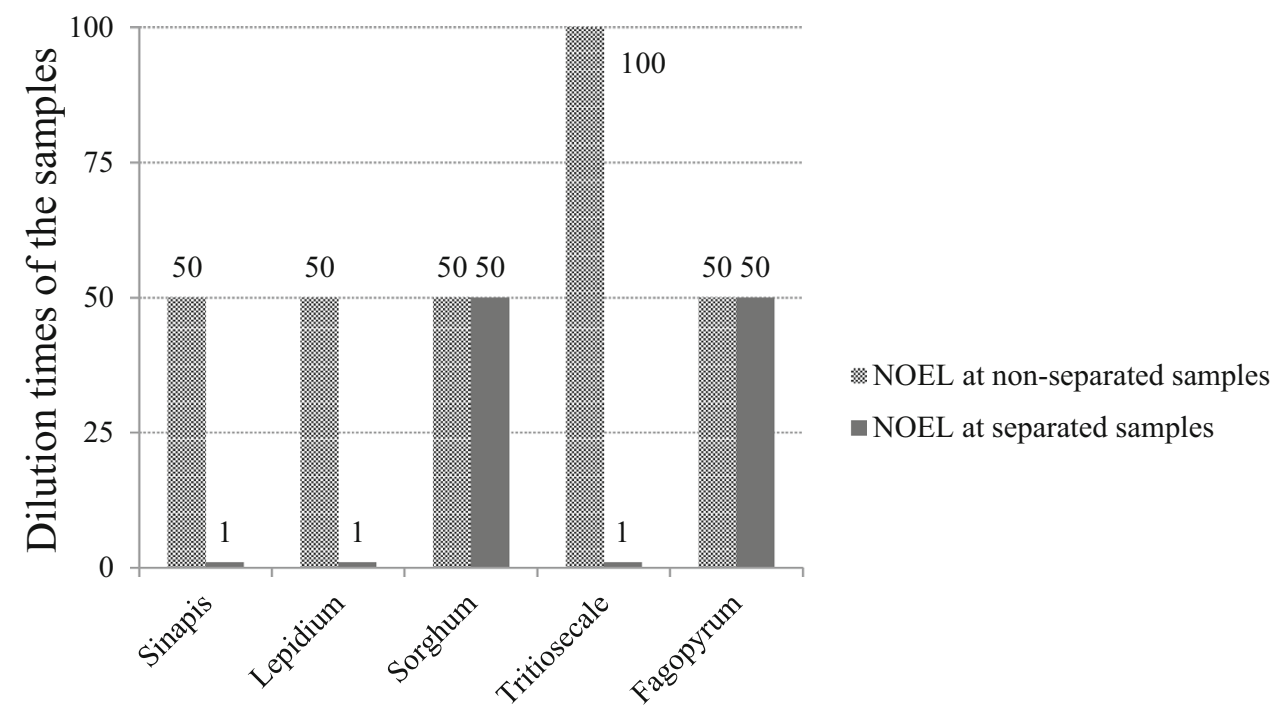

Type of seeds separation technology, as shown in Fig. 5. Sorghum and Fagopyrum were more sensitive to the chemical composition of the slurry. Together, the results show that the algae growth inhibition test and the Phytotoxkit tests presented the efficacy of the separation technology very well. With the help of this technology, agriculture could be more productive.

Determining the amount of slurry to field application is important for nutrient management. Slurry can be beneficial from an agricultural point of view in terms of nutrient and organic matter content, but its excessive use in the same area can be dangerous due to nitrogen $(\mathrm{N})$ and phosphorus $(\mathrm{P})$ contamination of groundwater (Bolan et al. 2004; Brock et al. 2006; Benke et al. 2008). According to Sterritt and Lester (1980), the agricultural use of sewage sludge can be a problem due to their heavy metal content. We know from the study by Pan et al. (2016), that if the nitrogen (ammonium, nitrite, nitrate) content is too high of the soil, it can have an inhibitory effect on plant germination. While in the experiment of Norouzi et al. (2016) tobacco (Nicotiana tabacum L.), alfalfa (Medicago sativa L.) and sorghum (Sorghum bicolor L.) responded well to 
higher dose of nitrogen treatment (150-300 $\left.\mathrm{kg} \mathrm{ha}^{-1}\right)$. The slurry tested by us, as described above, did not contain toxic ammonium (ammonium-nitrogen: $0.25 \mathrm{~g} \mathrm{~L}^{-1}$ ) and the farm under this study did not come into contact with heavy metal sources. Therefore, we attribute our toxicological results to the effect of other harmful substances in the slurry such as drugs used at the farm, detergents and natural hormonal substances in the slurry.

\section{Concluding remarks}

Yeast oestrogen screen shown in this study that the separation of the liquid and solid phases of slurry contributes to the reduction of oestrogenic substances. While this study is focusing on the investigation of the slurry samples of a specific year (2017) conducted on a particular cattle farm, it draws attention to the importance of the separation of the liquid and suspended solid phase of slurry before using it for agricultural purposes.

Based on the ecotoxicological studies, the growth inhibition of algae was 93\%, and the inhibition of the germination of higher plant seeds was $25 \%$, without separation. After separation of the phases, reproduction and germination were comparable with the negative control, moreover, some stimulation was detected, consequently, harmful substances (drugs, cleaning and disinfection products) were removed with the suspended solid phase.

Plant tests help with the risk management of slurry utilization, to determine the economical application of the slurry, to minimize, treat, monitor, and control the probability or impact of unfortunate events, such as bad germination and negative impact on plant growth. Moreover, this test suitable for the determination of the optimal amount of slurry utilization in order to get the optimal growth. Microbiotest applied in this study can be used effectively to the study of seed germination and can be adapted to any plant of interest.

To our best knowledge, this is the first detailed study of the liquid and solid phase of the slurry, which combines the toxicological evaluation with the measurement of oestrogenic effect of samples. Even we provide information about the oestrogen quantity and toxicity of the fractions of slurry in this study, the sorption of oestrogen compounds to the soil particles and their effects on plant growth and accumulation demands further research.

Acknowledgements This work was supported by the Széchenyi István University, Wittman Antal Plant-, Animal-, and Food Sciences Multidisciplinary Doctoral School, Mosonmagyaróvár and by the ÚNKP-20-3-II-SZE-18 New National Excellence Program of the Ministry for Innovation and Technology from the source of the National Research, Development and Innovation Fund. The authors would like to thank Orsolya Nagy for helping with bacteria tests.
Authors' contribution The study was designed by EG, IKSZ, JP, and PSZ, and the experimental work was performed by EG, IKSZ, and ME. The manuscript was written by EG, RG, BH, and IKSZ with feedback from JP.

Funding Open access funding provided by Széchenyi István University (SZE). Supported by the ÚNKP-20-3-II-SZE-18 New National Excellence Program of the Ministry for Innovation and Technology from the source of the National Research, Development and Innovation Fund.

\section{Declarations}

Conflict of interest The authors declare that they have no conflict of interest.

Open Access This article is licensed under a Creative Commons Attribution 4.0 International License, which permits use, sharing, adaptation, distribution and reproduction in any medium or format, as long as you give appropriate credit to the original author(s) and the source, provide a link to the Creative Commons licence, and indicate if changes were made. The images or other third party material in this article are included in the article's Creative Commons licence, unless indicated otherwise in a credit line to the material. If material is not included in the article's Creative Commons licence and your intended use is not permitted by statutory regulation or exceeds the permitted use, you will need to obtain permission directly from the copyright holder. To view a copy of this licence, visit http://creativecommons. org/licenses/by/4.0/.

\section{References}

Abhilash PC, Tripathi V, Edrisi SA, Dubey RK, Bakshi M, Dubey PK, Singh HB, Ebbs SD (2016) Sustainability of crop production from polluted lands. Energy Ecol Environ 1:54-65. https://doi. org/10.1007/s40974-016-0007-x

Adeel M, Song X, Wang Y, Francis D, Yang Y (2017) Environmental impact of estrogens on human, animal and plant life: a critical review. Environ Int 99:107-119. https://doi.org/10.1016/j.envint. 2016.12.010

Bai X, Acharya K (2019) Removal of seven endocrine disrupting chemicals (EDCs) from municipal wastewater effluents by a freshwater green alga. Environ Pollut 247:534-540. https://doi. org/10.1016/j.envpol.2019.01.075

Benke MB, Indaratne SP, Hao X, Chang C, Goh TB (2008) Trace element changes in soil after long-term cattle manure applications. Tech Rep Heavy Metals Environ. https://doi.org/10.2134/ jeq2007.0214

Bilal M, Barceló D, Iqbal HMN (2021) Occurrence, environmental fate, ecological issues, and redefining of endocrine disruptive estrogens in water resources. Sci Total Environ 800:149635. https://doi.org/10.1016/j.scitotenv.2021.149635

Biswas S, Shapiro CA, Kranz WL, Mader TL, Shelton DP, Snow DD, Bartelt-Hunt SL et al (2013) Current knowledge on the environmental fate, potential impact, and management of growth-promoting steroids used in the US beef cattle industry. J Soil Water Conserv 68(4):325-336. https://doi.org/10.2489/ jswc.68.4.325

Bowlin KM (2014) Effects of $\beta$-estradiol on germination and growth in Zea Mays L. Northwest Missouri State Univ. https://doi.org/ 10.1017/CBO9781107415324.004

Bolan N, Adriano D, Mahimairaja S (2004) Distribution and bioavailability of trace elements in livestock and poultry manure 
by-products. Crit Rev Environ Sci Technol 34(3):291-338. https://doi.org/10.1080/10643380490434128

Brock EH, Ketterings QM, Murray Mcbride M (2006) Copper and zinc accumulation in poultry and dairy manure- amended fields. Soil Sci 171(5):388-399. https://doi.org/10.1097/01.ss. 0000209360.62945 .95

Brown G (2006) The effects of estrogen on the growth and tuberization of potato plants (Solanum Tuberosum $\mathrm{Cv}$. 'Iwa') Grown in Liquid Tissue Culture Media. University of Canterbury, School of Biological Science

Burton CH (2007) The potential contribution of separation technologies to the management of livestock manure. Livest Sci 112(3):208-216. https://doi.org/10.1016/j.livsci.2007.09.004

Card ML, Schnoor JL, Chin YP (2012) Uptake of natural and synthetic estrogens by maize seedlings. J Agric Food Chem 60(34):8264-8271. https://doi.org/10.1021/jf3014074

Chaoui A, El Ferjani E (2013) $\beta$-estradiol protects embryo growth from heavy-metal toxicity in germinating lentil seeds. J Plant Growth Regul 32(3):636-645. https://doi.org/10.1007/s00344013-9332-X

Chen X, Li Y, Jiang L, Hu B, Wang L, An S, Zhang X (2021) Uptake, accumulation, and translocation mechanisms of steroid estrogens in plants. Sci Total Environ 753:141979. https://doi.org/10.1016/ j.scitotenv.2020.141979

Coldham NG, Dave M, Sivapathasundaram S, McDonnell DP, Connor C, Sauer MJ (1997) Evaluation of a recombinant yeast cell estrogen screening assay. Environ Health Perspect 105(7):734-742. https://doi.org/10.1289/ehp.97105734

CXXIX. Act (2007) Hungarian act on the protection of land

Decree 27/2006 (II.7) (2006) Hungarian government decree on protection of waters against nitrate pollution from agricultural sources

Decree 59/2008 (IV.29) (2008) Ministry of agriculture and rural development, hungarian decree on the detailed rules of the action program for the protection of waters against nitrate pollution of agricultural origin

Decree 90/2008 (VII.18) (2008) Ministry of agricultural and rural development, hungarian decree on the details of soil protection plan preparation

Erdal S, Dumlupinar R (2011) Exogenously treated mammalian sex hormones affect inorganic constituents of plants. Biol Trace Elem Res 143(1):500-506. https://doi.org/10.1007/s12011-0108857-0

EPA (Environmental Protection Agency) (1999) LC50 software programme, version 1.5. Center for Exposure Assessment Modelling (CEAM). Distribution Center

Findlay JWA, Dillard RF (2007) Appropriate calibration curve fitting in ligand binding assays. AAPS J 9(2):E260-E267. https://doi. org/10.1208/aapsj0902029

Fox JE (2004) Chemical communication threatened by endocrinedisrupting chemicals. Environ Health Perspect 112(6):648-653. https://doi.org/10.1289/ehp.6455

Franks CG (2006) Phytoremediation of Pharmaceuticals with SALIX EXIGUA. University of Lethbridge Research Repository, pp 1-216

Goeppert N, Dror I, Berkowitz B (2015) Fate and transport of free and conjugated estrogens during soil passage. Environ Pollut 206:80-87. https://doi.org/10.1016/j.envpol.2015.06.024

Goeppert N, Ishai D, Brian B (2014) Detection, fate and transport of estrogen family hormones in soil. Chemosphere 95:336-345. https://doi.org/10.1016/j.chemosphere.2013.09.039

Goodchild RG (1998) EU policies for the reduction of nitrogen in water: the example of the nitrates directive. Environ Pollut 102(SUPPL. 1):737-740. https://doi.org/10.1016/S02697491(98)80106-1
Goyal D, Yadav A, Prasad M, Singh TB, Shrivastav P, Ali A, Dantu PK, Mishra S (2020) Effect of heavy metals on plant growth: an overview. Contamin Agric. https://doi.org/10.1007/978-3-03041552-5_4

Gruiz K, Horváth B, Molnár M (2001) Környezettoxikológia. Müegyetemi Kiadó, Budapest

Guan M, Roddick JG (1988) Comparison of the effects of epibrassinolide and steroidal estrogens on adventitious root growth and early shoot development in mung bean cuttings. Physiol Plant 73(3):426-431. $\quad$ https://doi.org/10.1111/j.1399-3054.1988. tb00621.x

Hanselman TA, Graetz DA, Wilkie AC (2003) Manure-borne estrogens as potential environmental contaminants: a review. Environ Sci Technol 37(24):5471-5478. https://doi.org/10.1021/ es034410+

Hong LTA (2012) The YES assay as a tool to analyse endocrine disruptors in different matrices in vietnam. Institut für Nutzpflanzenwissenschaften und Ressourcenschutz (INRES) Lehr-und Forschungsbereich Pflanzenernährung der Rheinischen Friedrich-Wilhelms-Universität zu Bonn

Imai S, Shiraishi A, Gamo K, Watanabe I, Okuhata H, Miyasaka H, Ikeda K, Bamba T, Hirata K (2007) Removal of phenolic endocrine disruptors by portulaca oleracea. J Biosci Bioeng 103(5):420-426. https://doi.org/10.1263/jbb.103.420

ISO 19040-1 (2018) Water quality-determination of the estrogenic potential of water and waste water part 1: Yeast Estrogen Screen, Saccharomyces Cerevisiae

ISO 6341 (2012) Water quality determination of the inhibition of the mobility of daphnia magna straus, Cladocera, Crustacea-Acute Toxicity Test

ISO 8692 (2012) Water quality-fresh water algal growth inhibition test with unicellular green algae

Janeczko A, Skoczowski A (2005) Mammalian sex hormones in plants. Folia Histochem Cytobiol 43(2):71-79. https://doi.org/ $10.5603 / 4616$

Jiang Y, Colazo MG, Serpe MJ (2018) Poly (N -Isopropylacrylamide) microgel-based etalons for the label-free quantitation of estradiol-17 $\beta$ in aqueous solutions and milk samples. Anal Bioanal Chem https://doi.org/10.1007/s00216-018-1095-6

Kumar M, Sarma DK, Shubham S, Kumawat M, Verma V, Prakash A, Tiwari R (2020) Environmental endocrine-disrupting chemical exposure: role in non-communicable diseases. Front Public Health 8:553850. https://doi.org/10.3389/fpubh.2020.553850

Kopittke PM, Menzies NW, Wang P, McKenna BA, Lombi E (2019) Soil and the intensification of agriculture for global food security. Environ Int. https://doi.org/10.1016/j.envint.2019. 105078

Lai KM, Johnson KL, Scrimshaw MD, Lester JN (2000) Binding of waterborne steroid estrogens to solid phases in river and estuarine systems. Environ Sci Technol 34(18):3890-3894. https://doi.org/10.1021/es9912729

Lee LS, Carmosii N, Sassman SA, Dion HM, Maria SS (2007) Agricultural contributions of antimicrobials and hormones on soil and water quality. Adv Agron 93(SUPPL):1-68. https://doi. org/10.1016/S0065-2113(06)93001-6

Lehel J, Laczay P (2011) Toxikológia Budapest: Szent István University

Liu Y, Lin Y, Yen C, Miaw C, Chen T, Wu M, Hsieh C (2018) Identification, contribution, and estrogenic activity of potential EDCs in a river receiving concentrated livestock effluent in Southern Taiwan. Sci Total Environ 636:464-476. https://doi. org/10.1016/j.scitotenv.2018.04.031

Lopez-Rodriguez D, Franssen D, Bakker J, Lomniczi A, Parent AS (2021) Cellular and molecular features of EDC exposure: consequences for the GnRH network. Nat Rev Endocrinol 17:83-96. https://doi.org/10.1038/s41574-020-00436-3 
Louros VL, Lima DLD, Leitao JH, Esteves VI, Nadais G (2019) Determination of estrone and 17 alfa-ethinylestradiol in digested sludge by ultrasonic liquid extraction and high-performance liquid chromatography with fluorescence detection. J Sep Sci 42:1585-1592. https://doi.org/10.1002/jssc.201801114

Lu J, Wu J, Stoffella PJ, Wilson PC (2013) Analysis of Bisphenol A, nonylphenol, and natural estrogens in vegetables and fruits using gas chromatography-tandem mass spectrometry. J Agric Food Chem 61(1):84-89. https://doi.org/10.1021/jf304971k

Mhaouty-Kodja S, Naulé L, Capela D (2018) Sexual behavior: from hormonal regulation to endocrine disruption. Neuroendocrinology 107:400-416. https://doi.org/10.1159/000494558

MicroBioTest: Phytotoxkit Seed Germination and Early Growth Microbiotest with Higher Plants. Standard Operational Procedure. (2018) http://www.microbiotests.be/SOPs/Phytotoxkit SOP-A5.pdf

Mostofa MG, Amin O, Petersen S, Lægdsmand M (2012) Sorption of $17 \beta$-estradiol to pig slurry separates and soil in the soil-slurry environment. J Environ Qual 41(1):179. https://doi.org/10.2134/ jeq2011.0168

Hjorth M, Christensen KV, Christensen ML, Sommer SG (2010) Solid-liquid separation of animal slurry in theory and practice. A review. Agron Sustain Dev 30(1):2069

MSZ 21470:88 (1993) Hungarian standard. Environmental Protection. Testing of Soils. Pseudomonas Fluorescens Soiltoxicity Test

MSZ 21978:30 (1988) Hungarian Standard. (1988) Investigation of hazardous Waste. Microbiological Test of Soil. Azotobacter Agile Dehydrogenase Enzyme Activity Test

Nazari E, Suja F (2016) Effects of $17 \beta$-estradiol (E2) on aqueous organisms and its treatment problem: a review. Rev Environ Health 31(4):465-491. https://doi.org/10.1515/reveh-2016-0040

National Research Council (2014) A Framework to Guide Selection of Chemical Alternatives.Washington DC: The National Academies Press https://doi.org/10.17226/18872

Neeru N (2000) Azotobacter in Sustainable Agriculture. Edited by Narula Neeru. New Delhi

Nitrates Directive The Council of the European Communities (1999) Council Directive 91/676/EEC of 12 December Concerning the Protection of Waters against Pollution Caused by Nitrates from Agricultural Sources

Norouzi Y, Mohammadi GR, Nosratti I (2016) Effects of different nitrogen levels on phytotoxicity of some allelopathic crops. Acta Agric Slovenica 72:175-182. https://doi.org/10.14720/aas.2016. 107.1.17

Oliver MA, Gregory PJ (2015) Soil, food, security and human health: a review. Eur J Soil Sci 66(2):257-276. https://doi.org/10.1111/ ejss. 12216

Pan WL, Madsen IJ, Bolton RP, Graves L, Sistrunk T (2016) Ammonia/ammonium tocicity root symptoms induced by inorganic and organic fertilizers and placement. Agron J 108:6. https://doi.org/10.2134/agronj2016.02.0122
Parry R (1998) Agricultural phosphorus and water quality: a U.S. environmental protection agency perspective. J Environ Qual 27(2):258-261. https://doi.org/10.2134/jeq1998. $00472425002700020003 x$

Paulsen IT, Press CM, Ravel J, Kobayashi DY, Myers GSA, Mavrodi DV, DeBoy RT et al (2005) Complete genome sequence of the plant commensal pseudomonas fluorescens Pf-5. Nat Biotechnol 23(7):873-878. https://doi.org/10.1038/nbt1110

Pignotti E, Farré M, Barceló D, Dinelli E (2017) Occurrence and distribution of six selected endocrine disrupting compounds in surface- and groundwaters of the romagna area (North Italy). Environ Sci Pollut Res. https://doi.org/10.1007/s11356-0179756-0

Pimentel D, Burgess M (2013) Soil erosion threatens food production. Agriculture (switzerland) 3(3):443-463. https://doi.org/10.3390/ agriculture 3030443

Purvis IJ, Chotai D, Dykes CW, Lubahn DB, French FS, Wilson EM, Hobden AN (1991) An androgen-inducible expression system for saccharomyces cerevisiae. Gene 106:35-42. https://doi.org/ 10.1016/0378-1119(91)90563-Q

Rechsteiner D, Schrade S, Zähner M, Müller M, Hollender J, Bucheli TD (2020) Occurrence and fate of natural estrogens in swiss cattle and pig slurry. J Agric Food Chem 68(20):5545-5554

Routledge EJ, Sumpter JP (1996) Estrogenic activity of surfactants and some of their degradation products assessed using a recombinant yeast screen. Environ Toxicol Chem 15(3):241-248. https://doi.org/ 10.1002/etc.5620150303

Schröder P, Navarro-Aviñó J, Azaizeh H, Goldhirsh AG, Digregorio $\mathrm{S}$, Komives T, Langergraber $\mathrm{G}$ et al (2007) Using phytoremediation technologies to upgrade waste water treatment in Europe. Environ Sci Poll Res 14(147):490-497. https://doi.org/10.1065/ espr2006.12.373

Shi W, Wang L, Rousseau DPL, Lens PNL (2010) Removal of estrone, 17 $\alpha$-ethinylestradiol, and 17ß-estradiol in algae and duckweed-based wastewater treatment systems. Environ Sci Pollut Res 17(4):824-833. https://doi.org/10.1007/s11356-0100301-7

Sterritt RM, Lester JN (1980) The value of sewage sludge to agriculture and effects of the agricultural use of sludges contaminated with toxic elements: a review. Sci Total Environ 16:55-90. https://doi.org/10.1016/0378-1119(91)90563-Q

Wei H, Li Y, Ming Y, Wei L (2011) Presence and determination of manure-borne estrogens from dairy and beef cattle feeding operations in Northeast China. Bull Environ Contam Toxicol 86(5):465-469. https://doi.org/10.1007/s00128-011-0247-6

Zheng W, Yates SR, Bradford SA (2008) Analysis of steroid hormones in a typical dairy waste disposal system. Environ Sci Technol 42(2):530-535. https://doi.org/10.1021/es071896b 